\title{
Neural Network Analysis With Backpropogation In Predicting Human Development Index (HDI) Component by Regency/City In North Sumatera
}

\author{
Muhammad Noor Hasan Siregar \\ Universitas Graha Nusantara, Padangsidimpuan, Sumatera Utara \\ noor.siregar@gmail.com
}

\begin{abstract}
Human Development Index (HDI) measures human development outcomes based on a number of basic components of quality of life. As a measure of the quality of life, HDI is built through a basic three-dimensional approach. Data obtained from the Central Bureau of Statistics 2015 for Human Development Index (HDI) by Regency / City in North Sumatera Province consisting of 32 alternatives and with 4 parameters ie life expectancy (year), expectation, school length (\%), the average length of school (year) and per capita real expenditure (Rp). By using backpropagation obtained result of 6 testing of architecture pattern that is: 4-5-1, 4-10-1, 4-5-10-1, 4-10-5-1, 4-10-20-1 and 4- 15-20-1 obtained best architectural pattern is 4-10-20-1 with epoch 2126, error 0.0011757393, execution time 00:16 and accuracy $100 \%$.
\end{abstract}

Keywords: Prediction, Human Development Index (HDI), Backpropogation, JST

\section{Introduction}

Successful development, especially human development can be partially assessed by looking at how much of the most fundamental problems in society can be solved. These problems are poverty, unemployment, illiteracy, food security and democracy enforcement. But the problem is that the achievements of human development are partially varied where some aspects of development are successful and some other aspects of development fail. Quoting the first Human Development Report (HDR) 1990, human development is a process of multiplying human choices. Among the many options, the most important choice is to live long and healthy, to have the knowledgeable knowledge, and to have access to the resources needed to live properly.

Human Development Index (HDI) measures human development outcomes based on a number of basic components of quality of life. As a measure of the quality of life, HDI is built through a basic three-dimensional approach. These dimensions include long and healthy life; knowledge, and decent living. These three dimensions have a very broad sense because it is related to many factors. To measure the health dimension, use life expectancy at birth. Furthermore, to measure the dimensions of knowledge used combined indicators of literacy rates and the average length of school. To measure the living dimension, it is feasible to use the indicator of people's purchasing power to a number of basic needs which are seen from the average of per capita expenditure as income approach which represents the achievement of development for the decent living. To calculate the index of each component of HDI is used maximum and minimum limits which uses the maximum and minimum minimum parameters that are set up as shown in table 1 below:

Table 1. Maximum and Minimum Limits

\begin{tabular}{|c|l|c|c|l|}
\hline No & \multicolumn{1}{|c|}{ Components of HDI } & Maximum & Minimum & \multicolumn{1}{c|}{ Information } \\
\hline 1 & Angka Harapan Hidup (Tahun) & 85 & 25 & Standar UNDP \\
\hline 2 & Angka Melek Huruf (Persen) & 100 & 0 & Standar UNDP \\
\hline
\end{tabular}




\begin{tabular}{|c|l|c|c|l|}
\hline No & \multicolumn{1}{|c|}{ Components of HDI } & Maximum & Minimum & \multicolumn{1}{|c|}{ Information } \\
\hline 3 & Rata-rata Lama Sekolah (Tahun) & 15 & 0 & \\
\hline 4 & Daya Beli (Rupiah PPP) & 732.720 & $\begin{array}{c}300.000 \\
(1996)\end{array}$ & $\begin{array}{l}\text { Pengeluaran per Kapita } \\
\text { Riil Disesuaikan }\end{array}$ \\
\hline
\end{tabular}

This study takes data from the Central Bureau of Statistics 2015 for Human Development Index (HDI) by Regency / City in North Sumatera Province consisting of 32 alternatives and with 4 assessment parameters namely life expectancy (year), expectation, school length (\%), average school length (year) and real per capita expenditure (Rp). Increasing HDI is an achievement for the government of a region. Given that HDI is one of the indicators for the allocation of DAU (General Allocation Fund) to an area that has a very positive impact on the allocation of DAU, the higher the HDI than the greater the acquisition of DAU for an area that leads to improving the welfare of Indonesian society. imitations using Backpropagation method that predicts Human Development Index (HDI) based on regencies/cities in North Sumatera. This method is chosen because it is able to form and predict the HDI based on input from the given data. The method is done in two ways, namely training and testing. Data is divided into two parts, first data for the training process and second for testing. The training process aims to identify or search for the best architectural patterns, while the testing process is performed to produce the best accuracy based on the best pattern being treated. After achieving the training objectives based on the best pattern, then tested with new data to see the target accuracy using Matlab 6.1 software.

\section{Rudimentary}

\subsection{Artificial Intelegence}

AI is a field of study based on the premise that intelligent thought can be regarded as aform of computation - one that can be formalized and ultimately mechanized. To achievethis, however, two major issues need to be addressed. The first issue is knowledge representation, and the second is knowledge manipulation [1]. The main aim of Artificial Intelligence (AI) is to study how to build artificial systems that perform tasks normallyperformed by human beings. This concept was introduced in 1956 in the Darth mounth conference. From that moment on a lot of effort has been made and many goals have been achieved but unfortunately many failures as well. Today, the AI is a very important discipline and it includes a number of well-recognized and mature areas including Expert Systems [2-4], Fuzzy Logic [5-8], Genetic Algorithms [911], Language Processing, Logic Programming, Planning and Scheduling, Neural Networks and Robotics [12]. The general problem of simulating intelligence has been simplified tospecific sub-problems which have certain characteristics or capabilities that an intelligent system should exhibit. The following characteristics have received the most attention:

1. Deduction, reasoning, problem solving (embodied agents, neural networks, statistical approaches to $\mathrm{AI}$ );

2. Knowledge representation (ontologies);

3. Planning (multi-agent planning and cooperation);

4. Learning (machine learning);

5. Natural Language Processing (information retrieval - text mining, machine translation);

6. Motion and Manipulation (navigation, localization, mapping, motion planning);

7. Perception (speech recognition, facial, recognition, object recognition);

8. Social Intelligence (empathy simulation);

9. Creativity (artificial intuition, artificial imagination); and

10.General Intelligence (Strong AI). 


\subsection{Artificial Neural Networks (NN)}

Artificial Neural Network (ANN) is a computational model, which is based on Biological Neural Network. Artificial Neural Network is often called as Neural Network(NN) (See Figure 1). From Figure 1, to build artificial neural network, artificial neurons, also called as nodes, are interconnected $[13,14]$. The architecture of $\mathrm{NN}$ is very important forperforming a particular computation. Some neurons arearranged to take inputs fromoutside environment. These neurons are not connected with each other, so the arrangement of these neurons is in a layer, called as Input layer. All the neurons of input layer are producing some output, which is the input to next layer. The architecture of $\mathrm{NN}$ can be of single layer or multilayer. In a single layer Neural Network, only one input layer and one output layer is there, while in multilayer neural network, there can be one or more hidden layer.

An artificial neuron is an abstraction of biological neurons and the basic unitin an ANN $[15,16]$. The Artificial Neuron receives one or more inputs and sums them to produce an output. Usually the sums of each node are weighted, and the sum is passed through a function known as an activation or transfer function. The objective here is todevelop a data classification algorithm that will be used as a general-purpose classifier.To classify any database first, it is required to train the model. The proposed training algorithm used here is aHybrid BP-GA [17,18]. After successful training, user can give unlabeled data to be classified.

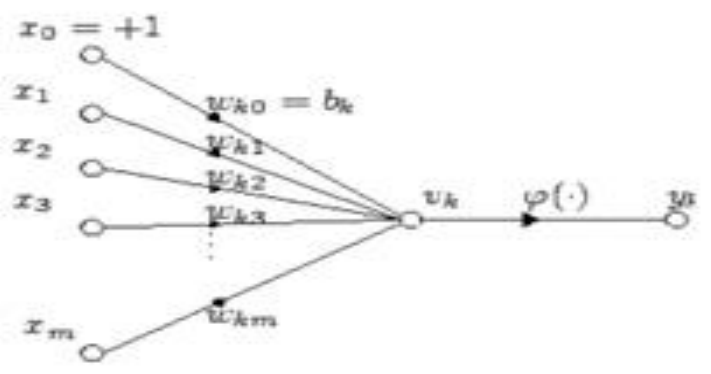

Figure 1. ANN Model

\subsection{Architecture of Backpropogation}

The back-propagation learning algorithm (BPLA) has become famous learning algorithms among ANNs. In the learning process, to reduce the in accuracy of ANNs, BPLAs use the gradient decent search method to adjust the connection weights. The structure of a backpropagation ANN is shown in Figure 2. The output of each neuron is the aggregation of the numbers of neurons of theprevious level multiplied by its corresponding weights. The input values are converted into output signals with the calculations of activation functions. Backpropagation ANNs have been widely and successfully applied in diverse applications, such as pattern recognition, location selectionand performance evaluations [19].

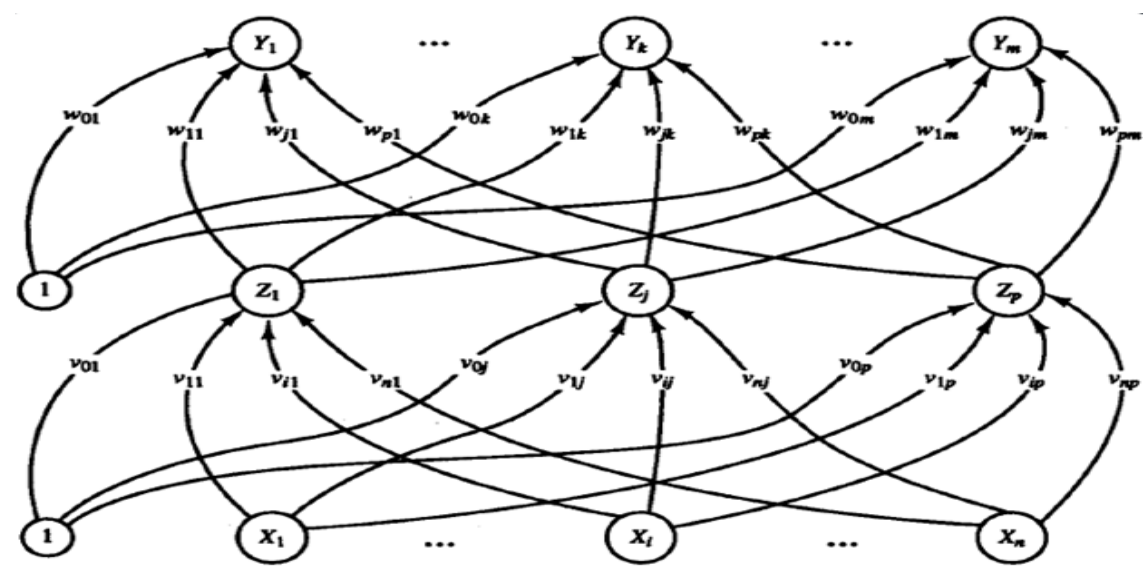

Figure 2. Back-propogation ANN 
Each of these layers must be either of the following:

1. Input Layer - This layer holds the input for thenetwork

2. Output Layer - This layer holds the output data, usually an identifier for the input.

3. Hidden Layer - This layer comes between the inputlayer and the output layer. They serve as apropagation point for sending data from the previous layer to the next layer [20].

\subsection{Backpropagation Neural Network}

Phases in Backpropagation Techniquealgorithm can bedivided into two phases: propagation and weight update.

Phase 1: Propagation

Each propagation involves the following steps:

1. Forward propagation of a training pattern's input is given through the neural network in order to generate the propagation's output activations.

2. Back propagation of the output activations propagation through the neural network using the training pattern's targetin order to generate the deltas of all output and hidden neurons.

Phase 2: Weight Update

For each weight-synapse:

1. Multiply its input activation and output delta to get thegradient of the weight.

2. Bring the weight in the direction of the gradient byadding a ratio of it from the weight.

This ratio impacts on the speed and quality of learning; itis called the learning rate. The sign of the gradient of aweight designates where the error is increasing; this is why the weight must be updated in the opposite direction. The phases 1 and 2 are repeated until the performance of the network is satisfactory $[21,22]$.

\section{Research and Methodology}

\subsection{Research Framework}

A framework of research work used in solving this research problem.

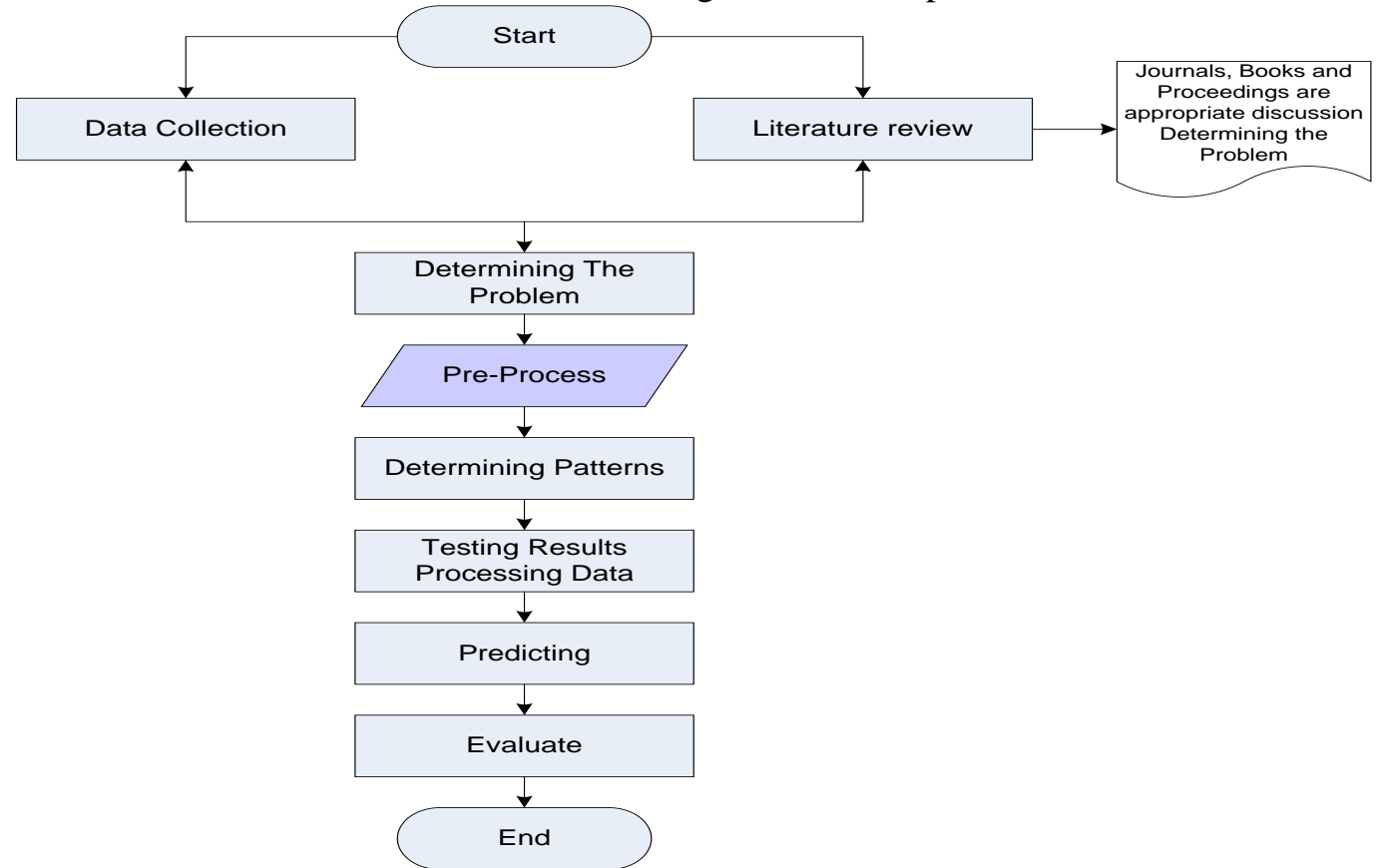

Figure 3. Research Framework 
Based on the framework in the picture above, each step can be described as follows :

1. Collecting Data

At this stage, the data is obtained from the Official Gazette (BRS) which is routinely published monthly by the Central Bureau of Statistics (BPS) Riau.

2. Library Studies

Literature study is the first step in this research, this literature study was conducted to complement the basic knowledge and theories used in this study.

3. Identifying Problems

In the identification phase of this problem, done after all the data is met then obtained the appropriate dataset to be done in the process of conversion process data obtained in accordance with the specified weight

4. Preprocess

Stages done is to make changes to some data types on dataset attributes with the aim to facilitate understanding of the contents of the record, also do the selection by considering the consistency of data, missing value and redundant on the data.

5. Determining the Model

The results of this stage are some models of artificial neural network with Backpropagation method to determine the pattern

6. Testing Results Data Processing

After the process of determining the model is completed, then performed the test phase against the results of data processing using Matlab Software R2011b (7.13)

7. Predicting

Prediction is done to compare the number with Neural Network model with the most accurate Backpropagation method.

8. Evaluate the End

Evaluate the end done to find out whether the testing of data processing results as expected.

\subsection{Data Used}

The data used in this research is the Component Data of Human Development Index (HDI) by Regency / City of 2015 which is sourced from BPS-National Socio-Economic Survey 2015 North Sumatera based on new calculation

\section{Table 1. Data Component of Human Development Index (HDI) by Regency / City} Year 2015

\begin{tabular}{|l|l|c|c|c|c|c|}
\hline \multirow{2}{*}{ No } & \multicolumn{1}{|c|}{ Regency / City } & $\begin{array}{c}\text { Life } \\
\text { Expectancy } \\
\text { (year) }\end{array}$ & $\begin{array}{c}\text { Life expectancy } \\
\text { Expectations } \\
(\%)\end{array}$ & $\begin{array}{c}\text { Average } \\
\text { school } \\
\text { length } \\
\text { (years) }\end{array}$ & $\begin{array}{c}\text { Real per } \\
\text { capita } \\
\text { expenditure } \\
\text { (000 Rp.) }\end{array}$ & HDI \\
\hline 1 & 01. N i a s & 68,97 & 11,77 & 4,76 & 6234 & 58,85 \\
2 & 02. Mandailing Natal & 61,58 & 12,77 & 7,63 & 9096 & 63,99 \\
3 & 03. Tapanuli Selatan & 63,74 & 13,06 & 8,27 & 10623 & 67,63 \\
4 & 04. Tapanuli Tengah & 66,59 & 12,40 & 8,02 & 9555 & 67,06 \\
5 & 05. Tapanuli Utara & 67,55 & 13,19 & 9,31 & 11079 & 71,32 \\
6 & 06. Toba Samosir & 69,14 & 13,18 & 10,08 & 11535 & 73,40 \\
7 & 07. Labuhanbatu & 69,36 & 12,57 & 8,75 & 10356 & 70,23 \\
8 & 08. A s a h a n & 67,37 & 12,49 & 8,32 & 10067 & 68,40 \\
9 & 09. Simalungun & 70,34 & 12,69 & 8,80 & 10728 & 71,24 \\
10 & 10. D a i r i & 67,78 & 12,80 & 8,69 & 9708 & 69,00
\end{tabular}




\begin{tabular}{|c|c|c|c|c|c|c|}
\hline \multirow[b]{2}{*}{ No } & \multirow[b]{2}{*}{ Regency / City } & \multicolumn{4}{|c|}{ Life expectancy } & \multirow[b]{2}{*}{ HDI } \\
\hline & & $\begin{array}{c}\text { Life } \\
\text { Expectancy } \\
\text { (year) }\end{array}$ & $\begin{array}{c}\text { Old School } \\
\text { Expectations } \\
(\%)\end{array}$ & $\begin{array}{l}\text { Average } \\
\text { school } \\
\text { length } \\
\text { (years) }\end{array}$ & $\begin{array}{l}\text { Real per } \\
\text { capita } \\
\text { expenditure } \\
\text { (000 Rp.) }\end{array}$ & \\
\hline 11 & 11. $\mathrm{K}$ a r o & 70,62 & 12,22 & 9,50 & 11800 & 72,69 \\
\hline 12 & 12. Deli Serdang & 71,00 & 12,52 & 9,48 & 11359 & 72,79 \\
\hline 13 & 13. $\mathrm{L}$ a n g k a t & 67,63 & 12,70 & 7,92 & 10364 & 68,53 \\
\hline 14 & 14. Nias Selatan & 67,66 & 11,96 & 4,64 & 6454 & 58,74 \\
\hline 15 & $\begin{array}{l}\text { 15. Humbang } \\
\text { Hasundutan }\end{array}$ & 68,10 & 13,15 & 8,90 & 6889 & 66,03 \\
\hline 16 & 16. Pakpak Bharat & 64,85 & 13,80 & 8,45 & 7496 & 65,53 \\
\hline 17 & 17. Samosir & 70,26 & 13,41 & 8,84 & 7698 & 68,43 \\
\hline 18 & 18. Serdang Bedagai & 67,47 & 12,31 & 8,08 & 10110 & 68,01 \\
\hline 19 & 19. Batu Bara & 65,80 & 11,96 & 7,74 & 9692 & 66,02 \\
\hline 20 & $\begin{array}{l}\text { 20. Padang Lawas } \\
\text { Utara }\end{array}$ & 66,50 & 11,87 & 8,91 & 9363 & 67,35 \\
\hline 21 & 21. Padang Lawas & 66,31 & 12,91 & 8,40 & 7955 & 65,99 \\
\hline 22 & $\begin{array}{l}\text { 22. Labuhanbatu } \\
\text { Selatan }\end{array}$ & 68,09 & 12,73 & 8,68 & 10319 & 69,67 \\
\hline 23 & 23. Labuhanbatu Utara & 68,70 & 12,12 & 8,31 & 11201 & 69,69 \\
\hline 24 & 24. Nias Utara & 68,59 & 12,40 & 6,06 & 5627 & 59,88 \\
\hline 25 & 25. Nias Barat & 67,94 & 12,33 & 5,74 & 5207 & 58,25 \\
\hline 26 & 71. S ib o lg a & 67,70 & 13,10 & 9,85 & 10765 & 71,64 \\
\hline 27 & 72. Tanjungbalai & 61,90 & 12,40 & 9,12 & 10326 & 66,74 \\
\hline 28 & 73. Pematangsiantar & 72,29 & 13,99 & 10,73 & 11388 & 76,34 \\
\hline 29 & 74. Tebing Tinggi & 70,14 & 12,23 & 10,06 & 11393 & 72,81 \\
\hline 30 & 75. M ed a n & 72,28 & 13,97 & 11,00 & 14191 & 78,87 \\
\hline 31 & 76. B i n j a i & 71,59 & 13,56 & 10,28 & 10098 & 73,81 \\
\hline 32 & 77. Padangsidimpuan & 68,32 & 14,48 & 10,47 & 9668 & 72,80 \\
\hline
\end{tabular}

Source: BPS-National Socio-Economic Survey, 2015

Keterangan :

From table 1 it is explained that input data (enter) consists of 4 variables, among others :
$\mathrm{X}_{1}=$ Life expectancy (year)
$\mathrm{X}_{2}=$ Old school expectations (\%)
$\mathrm{X}_{3}=$ Average school length (years)
$\mathrm{X}_{4}=$ Real expenditure per capita (000. Rp)
Target $=$ HDI

Data No. 1 through 16 will be used as training data. While data No. 17 to 32 will serve as data testing.

\subsection{Data Normalization}

Before being processed, the data is normalized first by using the Sigmoid function, represented by the equation (1).

$x^{\prime}=\frac{0.8(x-a)}{b-a}+0.1$ 


\subsubsection{Normalization of Data Training}

Table 2. Preliminary Training Data Before Normalization

\begin{tabular}{|c|c|c|c|c|c|}
\hline Data & $\mathbf{X}_{\mathbf{1}}$ & $\mathbf{X}_{\mathbf{2}}$ & $\mathbf{X}_{\mathbf{3}}$ & $\mathbf{X}_{\mathbf{4}}$ & Target \\
\hline 1 & 68,97 & 11,77 & 4,76 & 6234,00 & 58,85 \\
\hline 2 & 61,58 & 12,77 & 7,63 & 9096,00 & 63,99 \\
\hline 3 & 63,74 & 13,06 & 8,27 & 10623,00 & 67,63 \\
\hline 4 & 66,59 & 12,40 & 8,02 & 9555,00 & 67,06 \\
\hline 5 & 67,55 & 13,19 & 9,31 & 11079,00 & 71,32 \\
\hline 6 & 69,14 & 13,18 & 10,08 & 11535,00 & 73,40 \\
\hline 7 & 69,36 & 12,57 & 8,75 & 10356,00 & 70,23 \\
\hline 8 & 67,37 & 12,49 & 8,32 & 10067,00 & 68,40 \\
\hline 9 & 70,34 & 12,69 & 8,80 & 10728,00 & 71,24 \\
\hline 10 & 67,78 & 12,80 & 8,69 & 9708,00 & 69,00 \\
\hline 11 & 70,62 & 12,22 & 9,50 & 11800,00 & 72,69 \\
\hline 12 & 71,00 & 12,52 & 9,48 & 11359,00 & 72,79 \\
\hline 13 & 67,63 & 12,70 & 7,92 & 10364,00 & 68,53 \\
\hline 14 & 67,66 & 11,96 & 4,64 & 6454,00 & 58,74 \\
\hline 15 & 68,10 & 13,15 & 8,90 & 6889,00 & 66,03 \\
\hline 16 & 64,85 & 13,80 & 8,45 & 7496,00 & 65,53 \\
\hline
\end{tabular}

Information :

a. Training data is taken from table 1 , ie data number 1 through number 16 based on life expectancy (X1), school life expectancy (X2), average school length (X3) and real expenditure per capita (X4). While Target based on the value of HDI.

b. The maximum value (b) of the table 2 dataset is 11800.00 . The minimum value (a) is 4.64 .

Table 3. Training Data After Normalization

\begin{tabular}{|c|c|c|c|c|c|}
\hline Data & $\mathbf{X 1}$ & $\mathbf{X 2}$ & $\mathbf{X 3}$ & $\mathbf{X 4}$ & Target \\
\hline 1 & 0,104363 & 0,100484 & 0,100008 & 0,522496 & 0,103677 \\
\hline 2 & 0,103862 & 0,100551 & 0,100203 & 0,716606 & 0,104025 \\
\hline 3 & 0,104008 & 0,100571 & 0,100246 & 0,820172 & 0,104272 \\
\hline 4 & 0,104202 & 0,100526 & 0,100229 & 0,747737 & 0,104234 \\
\hline 5 & 0,104267 & 0,100580 & 0,100317 & 0,851099 & 0,104522 \\
\hline 6 & 0,104375 & 0,100579 & 0,100369 & 0,882027 & 0,104664 \\
\hline 7 & 0,104390 & 0,100538 & 0,100279 & 0,802063 & 0,104449 \\
\hline 8 & 0,104255 & 0,100532 & 0,100250 & 0,782462 & 0,104324 \\
\hline 9 & 0,104456 & 0,100546 & 0,100282 & 0,827293 & 0,104517 \\
\hline 10 & 0,104282 & 0,100553 & 0,100275 & 0,758114 & 0,104365 \\
\hline 11 & 0,104475 & 0,100514 & 0,100330 & 0,900000 & 0,104615 \\
\hline 12 & 0,104501 & 0,100534 & 0,100328 & 0,870090 & 0,104622 \\
\hline 13 & 0,104272 & 0,100547 & 0,100222 & 0,802606 & 0,104333 \\
\hline 14 & 0,104274 & 0,100496 & 0,100000 & 0,537417 & 0,103669 \\
\hline 15 & 0,104304 & 0,100577 & 0,100289 & 0,566920 & 0,104164 \\
\hline 16 & 0,104084 & 0,100621 & 0,100258 & 0,608089 & 0,104130 \\
\hline
\end{tabular}


Information :

a. By using sigmoid function based on table 2, it will get data normalization table 2 as follows

$$
x^{\prime}=\frac{0,8(68,97-4,64)}{11800,00-4,64}+0,1=0,104363
$$

b. Then will get result Normalisasi data $X_{1}=0,104363$. So on for all data, normalized by using the same function.

\subsubsection{Normalization of Data Testing}

Table 4. Preliminary Testing Data Before Normalization

\begin{tabular}{|c|c|c|c|c|c|}
\hline Data & $\mathbf{X}_{\mathbf{1}}$ & $\mathbf{X 2}$ & $\mathbf{X 3}$ & $\mathbf{X 4}$ & Target \\
\hline 17 & 70,26 & 13,41 & 8,84 & 7698,00 & 68,43 \\
\hline 18 & 67,47 & 12,31 & 8,08 & 10110,00 & 68,01 \\
\hline 19 & 65,80 & 11,96 & 7,74 & 9692,00 & 66,02 \\
\hline 20 & 66,50 & 11,87 & 8,91 & 9363,00 & 67,35 \\
\hline 21 & 66,31 & 12,91 & 8,40 & 7955,00 & 65,99 \\
\hline 22 & 68,09 & 12,73 & 8,68 & 10319,00 & 69,67 \\
\hline 23 & 68,70 & 12,12 & 8,31 & 11201,00 & 69,69 \\
\hline 24 & 68,59 & 12,40 & 6,06 & 5627,00 & 59,88 \\
\hline 25 & 67,94 & 12,33 & 5,74 & 5207,00 & 58,25 \\
\hline 26 & 67,70 & 13,10 & 9,85 & 10765,00 & 71,64 \\
\hline 27 & 61,90 & 12,40 & 9,12 & 10326,00 & 66,74 \\
\hline 28 & 72,29 & 13,99 & 10,73 & 11388,00 & 76,34 \\
\hline 29 & 70,14 & 12,23 & 10,06 & 11393,00 & 72,81 \\
\hline 30 & 72,28 & 13,97 & 11,00 & 14191,00 & 78,87 \\
\hline 31 & 71,59 & 13,56 & 10,28 & 10098,00 & 73,81 \\
\hline 32 & 68,32 & 14,48 & 10,47 & 9668,00 & 72,80 \\
\hline
\end{tabular}

Information:

a. Data Testing is taken based on table 1 , ie data number 17 to number 32 based on life expectancy $\left(\mathrm{X}_{1}\right)$, school long expectation $\left(\mathrm{X}_{2}\right)$, average school length $\left(\mathrm{X}_{3}\right)$ and real expenditure per capita $\left(\mathrm{X}_{4}\right)$. While Target based on the value of HDI.

b. The maximum value (b) of the table 2 dataset is 14191.00 . The minimum value (a) is 5.74.

Table 5. Data Testing After Normalization

\begin{tabular}{|c|c|c|c|c|c|}
\hline Data & $\mathbf{X 1}$ & $\mathbf{X 2}$ & $\mathbf{X 3}$ & $\mathbf{X 4}$ & Target \\
\hline 17 & 0,103639 & 0,100433 & 0,100175 & 0,533817 & 0,103536 \\
\hline 18 & 0,103481 & 0,100371 & 0,100132 & 0,669846 & 0,103512 \\
\hline 19 & 0,103387 & 0,100351 & 0,100113 & 0,646272 & 0,103400 \\
\hline 20 & 0,103427 & 0,100346 & 0,100179 & 0,627717 & 0,103475 \\
\hline 21 & 0,103416 & 0,100404 & 0,100150 & 0,548311 & 0,103398 \\
\hline 22 & 0,103516 & 0,100394 & 0,100166 & 0,681632 & 0,103605 \\
\hline 23 & 0,103551 & 0,100360 & 0,100145 & 0,731374 & 0,103607 \\
\hline 24 & 0,103545 & 0,100376 & 0,100018 & 0,417020 & 0,103053 \\
\hline 25 & 0,103508 & 0,100372 & 0,100000 & 0,393333 & 0,102961 \\
\hline
\end{tabular}




\begin{tabular}{|c|c|c|c|c|c|} 
Data & $\mathbf{X 1}$ & $\mathbf{X 2}$ & $\mathbf{X 3}$ & $\mathbf{X 4}$ & Target \\
\hline 26 & 0,103494 & 0,100415 & 0,100232 & 0,706785 & 0,103717 \\
\hline 27 & 0,103167 & 0,100376 & 0,100191 & 0,682027 & 0,103440 \\
\hline 28 & 0,103753 & 0,100465 & 0,100281 & 0,741920 & 0,103982 \\
\hline 29 & 0,103632 & 0,100366 & 0,100244 & 0,742202 & 0,103783 \\
\hline 30 & 0,103753 & 0,100464 & 0,100297 & 0,900000 & 0,104124 \\
\hline 31 & 0,103714 & 0,100441 & 0,100256 & 0,669169 & 0,103839 \\
\hline 32 & 0,103529 & 0,100493 & 0,100267 & 0,644918 & 0,103782 \\
\hline
\end{tabular}

Information:

a. By using sigmoid function based on table 4 , it will be obtained data normalization table 2 as follows :

$$
x^{\prime}=\frac{0,8(70,26-5,74)}{14191,00-5,74}+0,1=0,103639
$$

b. Then will get result Normalization data X1 0,103639. So on for all data, normalized by using the same function.

\section{Results and Discussion}

\subsection{Analysis}

Creating network architecture initialization is the most important thing in programming backpropagation with the Matlab application. The network architecture in this study uses 6 architectural models, among others: 4-5-1 (4 inputs, 5 hidden hidden neurons, 1 output), 4-10-1 (4 inputs, 10 hidden layer neurons, 1 output), 4 -5-10-1 (4 inputs, hidden layer using 5 neurons and 10 neurons, 1 output), 4-10-15-1 (4 inputs, hidden layer using 10 neurons and 15 neurons, 1 output), 4-10 -20-1 (4 inputs, hidden layer using 10 neurons and 20 neurons, 1 output), 4-15-201 (4 inputs, hidden layer using 15 neurons and 20 neurons, 1 output). The activation function used is a bipolar sigmoid function (tansig). Minimum error 0.001-0.01 with maximum epoch 10000 and learning rate 0.01 .

\subsection{Results}

Of the 6 models of network architecture used, the best architectural model is 4-10-20-1 with the accuracy rate reaching $100 \%$.

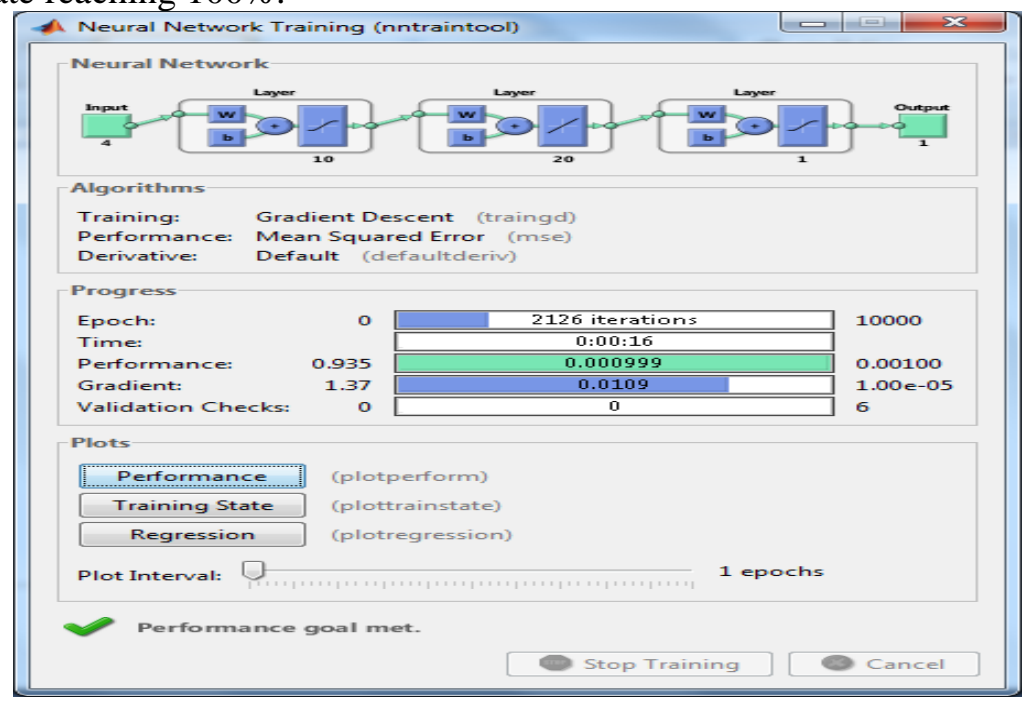

Information:

Figure 2. Results of Training Data 4-10-20-1

Epoch that happened for 2126 iteration with 45 seconds duration. 
Table 6. Data Training And Testing Backpropagation

\begin{tabular}{|c|c|c|c|c|c|c|}
\hline \multirow{2}{*}{ No } & \multirow{2}{*}{ Architecture } & \multicolumn{3}{|c|}{ Training } & \multicolumn{2}{c|}{ Testing } \\
\cline { 3 - 7 } & & Epoch & Time & MSE & MSE & Accuracy \\
\hline 1 & $4-5-1$ & 2440 & $00: 16$ & 0,0010272921 & 0,2406947561 & $0 \%$ \\
\hline 2 & $4-10-1$ & 4199 & $00: 26$ & 0,0006399902 & 0,6233873936 & $0 \%$ \\
\hline 3 & $4-5-10-1$ & 891 & $00: 06$ & 0,0010891741 & 0,0112097187 & $69 \%$ \\
\hline 4 & $4-10-15-1$ & 2330 & $00: 19$ & 0,0011297433 & 0,0052151298 & $44 \%$ \\
\hline 5 & $4-10-20-1$ & 2126 & $00: 16$ & 0,0011757393 & 0,4250456613 & $100 \%$ \\
\hline 6 & $4-15-20-1$ & 1956 & $00: 16$ & 0,0013123777 & 0,0752453448 & $56 \%$ \\
\hline
\end{tabular}

\section{Conclution}

Based on the description of the previous discussion results can be concluded that the best architectural model used is $4-10-20-1$ with $100 \%$ accuracy rate. Thus, this model is good enough to be used to predict data.

\section{References}

[1] Khalid, Mohd Sazali, et al. "Teaching and Learning Using Computers: How Should We Tread on Its' Changing Technology?." International Journal of Emerging Technologies in Learning 9.5 (2014).

[2] Chiroma, H., Abdulkareem, S., Abubakar, A.I. and Herawan, T., 2014. Kernel functions for the support vector machine: comparing performances on crude oil price data. In Recent Advances on Soft Computing and Data Mining (pp. 273-281). Springer International Publishing.

[3] Hakim, R.F., Sari, E.N. and Herawan, T., 2014. Soft Solution of Soft Set Theory for Recommendation in Decision Making. In Recent Advances on Soft Computing and Data Mining (pp. 313-324). Springer International Publishing.

[4] Lasisi, A., Ghazali, R. and Herawan, T., 2014. Comparative performance analysis of negative selection algorithm with immune and classification algorithms. In Recent Advances on Soft Computing and Data Mining (pp. 441-452). Springer International Publishing.

[5] Handaga, B., Herawan, T. and Deris, M.M., 2012. FSSC: An Algorithm for Classifying Numerical Data Using Fuzzy Soft Set Theory. International Journal of Fuzzy System Applications (IJFSA), 2(4), pp.29-46.

[6] Herawan, T., Abdullah, Z., Chiroma, H., Sari, E.N., Ghazali, R. and Nawi, N.M., 2014, September. Cauchy criterion for the Henstock-Kurzweil integrability of fuzzy numbervalued functions. In Advances in Computing, Communications and Informatics (ICACCI, 2014 International Conference on (pp. 1329-1333). IEEE.

[7] Ma, X., Qin, H., Sulaiman, N., Herawan, T. and Abawajy, J.H., 2014. The parameter reduction of the interval-valued fuzzy soft sets and its related algorithms. IEEE Transactions on Fuzzy Systems, 22(1), pp.57-71.

[8] Yanto, I.T.R., Ismail, M.A. and Herawan, T., 2016. A modified Fuzzy k-Partition based on indiscernibility relation for categorical data clustering. Engineering Applications of Artificial Intelligence, 53, pp.41-52.

[9] Abubakar, A.I., Zeki, A., Chiroma, H. and Herawan, T., 2014. Investigating Rendering Speed and Download Rate of Three-Dimension (3D) Mobile Map Intended for Navigation Aid Using Genetic Algorithm. In Recent Advances on Soft Computing and Data Mining (pp. 261-271). Springer International Publishing. 
[10] Qin, H., Ma, X., Herawan, T. and Zain, J.M., 2012, May. An improved genetic clustering algorithm for categorical data. In Pacific-Asia Conference on Knowledge Discovery and Data Mining (pp. 100-111). Springer Berlin Heidelberg.

[11] Shah, H., Ghazali, R., Nawi, N.M., Deris, M.M. and Herawan, T., 2013. Global artificial bee colony-Levenberq-Marquardt (GABC-LM) algorithm for classification. International Journal of Applied Evolutionary Computation (IJAEC), 4(3), pp.58-74.

[12] Castaño, B., Moreno, Á., Carbajo, M. and de Pedro, J., 2008. Artificial Intelligence and Bluetooth Techniques in a Multi-user M-learning Domain. IJCSA, 5(1), pp.1-13.

[13] Abubakar, A.I., Khan, A., Nawi, N.M., Rehman, M.Z., Wah, T.Y., Chiroma, H. and Herawan, T., 2016. Studying the Effect of Training Levenberg Marquardt Neural Network by Using Hybrid Meta-Heuristic Algorithms. Journal of Computational and Theoretical Nanoscience, 13(1), pp.450-460.

[14] Chiroma, H., Abdul-kareem, S., Ibrahim, U., Ahmad, I.G., Garba, A., Abubakar, A., Hamza, M.F. and Herawan, T., 2015. Malaria severity classification through JordanElman neural network based on features extracted from thick blood smear. Neural Network World, 25(5), p.565.

[15] Husaini, N.A., Ghazali, R., Nawi, N.M., Ismail, L.H., Deris, M.M. and Herawan, T., 2014. Pi-Sigma Neural Network For A One-Step-Ahead Temperature Forecasting. International Journal of Computational Intelligence and Applications, 13(04), p.1450023.

[16] Nawi, N.M., Rehman, M.Z., Aziz, M.A., Herawan, T. and Abawajy, J.H., 2014, November. Neural network training by hybrid accelerated cuckoo particle swarm optimization algorithm. In International Conference on Neural Information Processing (pp. 237-244). Springer International Publishing.

[17] Nawi, N.M., Rehman, M.Z., Aziz, M.A., Herawan, T. and Abawajy, J.H., 2014, November. An Accelerated Particle Swarm Optimization Based Levenberg Marquardt Back Propagation Algorithm. In International Conference on Neural Information Processing (pp. 245-253). Springer International Publishing.

[18] Chiroma, H., Abdul-Kareem, S., Muaz, S.A., Khan, A., Sari, E.N. and Herawan, T., 2014, October. Neural Network Intelligent Learning Algorithm for Inter-related Energy Products Applications. In International Conference in Swarm Intelligence (pp. 284-293). Springer International Publishing.

[19] Che, Z.G., Chiang, T.A. and Che, Z.H., 2011. Feed-forward neural networks training: A comparison between genetic algorithm and back-propagation learning algorithm. International Journal of Innovative Computing, Information and Control, 7(10), pp.58395850 .

[20] Choudhary, N.Y., Patil, M.R., Bhadade, U. and Chaudhari, B.M., 2013. Signature Recognition \& Verification System Using Back Propagation Neural Network. International Jorunal of IT, Engineering and Applied Sciences Research (IJIEASR), 2(1), pp.1-8.

[21] Baboo, S.S. and Shereef, I.K., 2010. An efficient weather forecasting system using artificial neural network. International journal of environmental science and development, 1(4), p.321.

[22] Sumijan, A. P. Windarto, A. Muhammad, and Budiharjo, "Implementation of Neural Networks in Predicting the Understanding Level of Students Subject," Int. J. Softw. Eng. Its Appl., vol. 10, no. 10, pp. 189-204, 2016. 


\section{Authors}

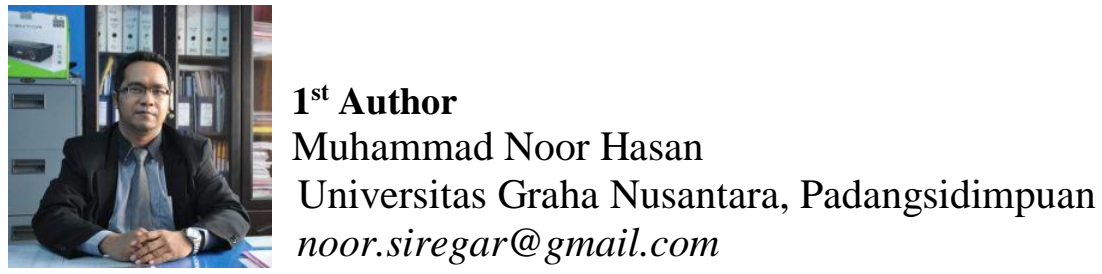

